\title{
Success Factors for the Implementation of Separate Collection Systems
}

\author{
Roman Maletz
}

\begin{abstract}
Within the symposium "Waste Reduction and Recycling: Challenges and Trends for Source Separation," which was held from June 6 to 10, 2016, participants discussed the successful implementation of separate collection. The conclusions of this symposium are summarized in this chapter and consider some additional aspects. It is focused on the situation in China and Germany, but they are also applicable to different situations and regions around the world. For countries with rising waste management challenges, source separation has been proven to be one of the fundamental solutions for the sustainable handling of resources and achievement of a circular economy. The driving forces for establishing of efficient collection schemes are described in this chapter, referring back to the previous chapters of the book, where the challenges and possibilities for different fractions and separation technologies are presented.
\end{abstract}

Keywords Collection scheme, Developing countries, Recycling, Source separation, Success factors, Waste management

\section{Contents}

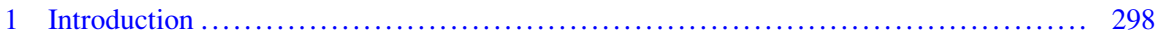

2 Separate Collection Schemes ........................................... 299

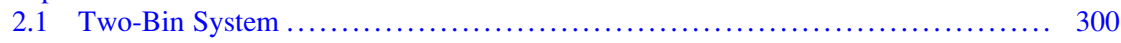

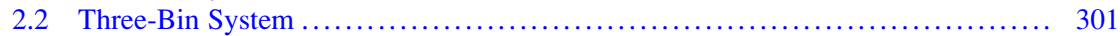

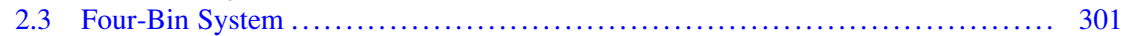

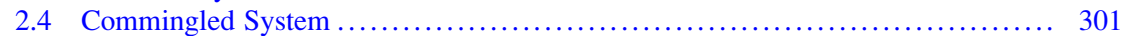

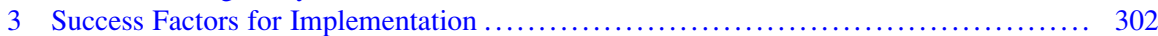

3.1 Separation of the Most Suitable Waste Streams ........................... 302

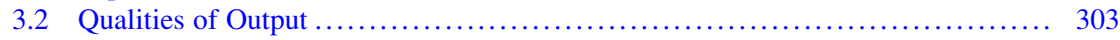

R. Maletz $(\bowtie)$

Institute of Waste Management and Circular Economy, Technische Universität Dresden,

Dresden, Germany

e-mail: roman.maletz@tu-dresden.de 


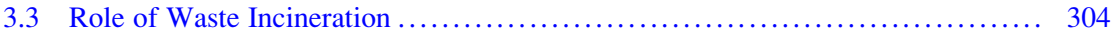

3.4 Separation Technology .............................................. 304

3.5 Integration of the Informal Sector .................................. 305

3.6 Measures for the Strict Enforcement of Legislative Regulations on Source

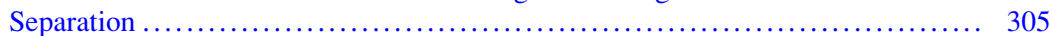

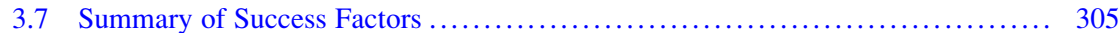

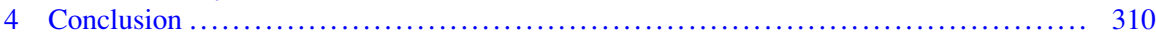

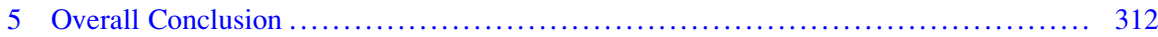

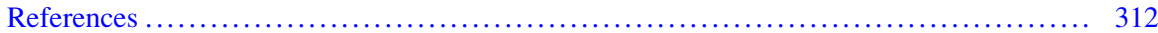

\section{Introduction}

In the symposium "Waste Reduction and Recycling: Challenges and Trends for Source Separation," which was held from June 6 to 10, 2016, participants discussed the successful implementation of separate collection. The conclusions of the symposium summarized in this chapter consider some additional aspects. The conclusions and summarized results from this book focus on the situation in China and Germany, but can also be applicable to different situations and regions around the world.

Separate collection is seen as one of the most important instruments to reducing residual waste streams and therefore reducing the landfilling of waste (e.g., see [1-5]). Landfilling leads to land consumption, landfill gas emissions (see [6]), and the depletion of resources that could instead be looped back into the economy through recycling and recovery.

Source separation reduces the GHG balance of a country (see [7]), avoids land consumption, and can lead to regional economic benefits using locally recycled materials instead of imported raw materials (see [8]). These benefits were described in the previous chapters. The conditions needed to implement and run a separate collection system should be highlighted in this concluding chapter.

Actually, it can be divided between success factors for source separation itself, measured by ecological and economic parameters, and success factors for the implementation of new waste management schemes. In this paper, separate collection schemes for countries which have no or rudimentary segregation systems are meant.

Before looking at the success factors, some different kinds of source separation schemes are shown briefly again (for further information on the different types, see [9-11]), because the collection scheme is one of the most influential factors in the amount of resultant recycling material. 


\section{Separate Collection Schemes}

European countries (besides Japan) have one of the most developed source separation systems in the world. Therefore, as an example, the systems of 28 EU capitals have been investigated by BIPRO/CRI [12]. According to their system, the performance of the systems differs. The possible configurations used in the different EU capitals are shown in Fig. 1.

The systems can be classified by collected single fractions and collection type. Usually relevant single collected fractions are: biowaste, paper, plastic (or sometimes used for packaging waste), metals (sometimes included in packaging waste), and WEEE.

For implementation planning also of high importance is the collection type, which means: collection at the household level, bring points (recycling points) or civic amenity cites (i.e. recycling yards) (see also [11]). Differences for the German situation are shown in Table 1.

\begin{tabular}{|c|c|c|c|c|c|}
\hline Collection type & Paper & Glass & Plastic & Metal & Bio-waste \\
\hline $\begin{array}{l}\text { Door-to-door } \\
\text { (single fraction) }\end{array}$ & $\begin{array}{l}\text { AT, BE, BG, CY, DE, } \\
\text { DK, FI, HU, IT, LU, } \\
\text { LV, NL, SI, UK }\end{array}$ & $\begin{array}{l}\text { BG, FI, LU, LV, } \\
\text { NL, SI, MT }\end{array}$ & AT, LV, NL, DK & FI, NL, DK & $\begin{array}{l}\text { AT, BE, CZ, DE, } \\
\text { FI, EE, IT, HU, } \\
\text { LU, NL, SI, SE, } \\
\text { IE, UK }\end{array}$ \\
\hline $\begin{array}{l}\text { Co-mingled } \\
\text {...plastic + metal }\end{array}$ & & & \multirow{2}{*}{\multicolumn{2}{|c|}{$B E, B G, C Y, D E, F R, I T, H U, L U, S I$}} & \\
\hline$\ldots 3$ fractions & \multicolumn{2}{|c|}{$\begin{array}{l}\text { RO, MT: paper, plastic, metal } \\
\text { UK: plastic, metal, glass }\end{array}$} & & & \\
\hline ...all in one bin & \multicolumn{4}{|c|}{ EL, IE: paper, glass, plastic, metal } & \\
\hline \multirow[t]{2}{*}{ Bring points } & \multirow[b]{2}{*}{$\begin{array}{l}\text { CZ, EE, ES, FR, HR, } \\
\text { LT, PT, PL, SE, SK }\end{array}$} & \multirow{2}{*}{$\begin{array}{l}\text { AT, BE, DK, CY, } \\
C Z, D E, E E, E S \text {, } \\
\text { FR, HR, IT, HU, } \\
\text { LT, PT, PL, RO, } \\
\text { SE, SK }\end{array}$} & SE & AT, EE, SE & \multirow[t]{2}{*}{ ES } \\
\hline & & & \multicolumn{2}{|c|}{$\begin{array}{l}\text { ES, HR, LT, PT, PL } \\
\text { (all plastic/metal in one container) }\end{array}$} & \\
\hline Civic amenity sites & \multicolumn{5}{|c|}{$\begin{array}{l}\text { Primary collection: CZ (metal waste), SK (metal and bio-waste), LV (metal) } \\
\text { Addition collection of all waste streams: all countries } \\
\text { PL: rare distribution of civic amenity sites }\end{array}$} \\
\hline
\end{tabular}

Fig. 1 Overview of collection systems in place in the $28 \mathrm{EU}$ countries (primary systems only), source: BIPRO/CRI [12]. AT Austria, $B E$ Belgium, $B G$ Bulgaria, $C Y$ Cyprus, $C Z$ Czech Republic, $D E$ Germany, $D K$ Denmark, EE Estonia, EL Greece, ES Spain, FI Finland, FR France, HR Croatia, $H U$ Hungary, IE Ireland, IT Italy, $L T$ Lithuania, $L U$ Luxemburg, $L V$ Latvia, $M T$ Malta, $N L$ Netherlands, $P L$ Poland, PT Portugal, RO Romania, SE Sweden, SI Slovenia, SK Slovakia, UK United Kingdom 
Table 1 Differences for the German situation, investigation by Dehoust and Christiani [13], no misthrow with a bring system is assumed

\begin{tabular}{l|l|l}
\hline & Pickup system $\mathrm{kg} /(\mathrm{cap} * \mathrm{a})$ & Bring system $\mathrm{kg} /(\mathrm{cap} * \mathrm{a})$ \\
\hline Average collection yield & 30 & 11 \\
\hline Average sorting residuals of yield & 10 & - \\
\hline Balance & 20 & 11 \\
\hline
\end{tabular}

Table 2 Collection schemes implemented in Germany as the standard system or as pilot projects (each color stands for one bin at the household level), derived from Schröer et al. [14]

\begin{tabular}{|c|c|c|c|c|c|c|}
\hline \multirow{2}{*}{ Concept } & \multirow{2}{*}{ Bio waste } & Residual waste & \multirow{2}{*}{$\begin{array}{c}\text { Packaging } \\
\text { waste }\end{array}$} & \multirow{2}{*}{$\begin{array}{r}\text { Small } \\
\text { WEEE }\end{array}$} & \multirow{2}{*}{$\begin{array}{c}\text { Paper } \\
\text { cardboard }\end{array}$} & \multirow{2}{*}{ Glass } \\
\hline & & \begin{tabular}{|l|l|} 
No valuables & Valuables \\
\end{tabular} & & & & \\
\hline Standard bin configuration & & & & $\begin{array}{c}\text { Civic } \\
\text { amenity } \\
\text { site }\end{array}$ & $\begin{array}{c}\text { Bin/bring } \\
\text { points }\end{array}$ & Bring points \\
\hline Packaging waste in the residuals bin & & & & $\begin{array}{c}\text { Civic } \\
\text { amenity } \\
\text { site }\end{array}$ & $\begin{array}{l}\text { Bin/bring } \\
\text { points }\end{array}$ & Bring points \\
\hline Dry valuables bin & & & & $\begin{array}{c}\text { Civic } \\
\text { amenity } \\
\text { site } \\
\end{array}$ & $\begin{array}{c}\text { Bin/bring } \\
\text { points }\end{array}$ & Bring points \\
\hline $\begin{array}{l}\text { Valuables bin plus small WEEE } \\
\text { ("Yellow bin plus") }\end{array}$ & & & & & $\begin{array}{c}\text { Bin/bring } \\
\text { points }\end{array}$ & Bring points \\
\hline
\end{tabular}

According to the specific situation in the collection area and underlying waste management strategies, different combinations and numbers of household bins and other collection spots are possible with the most successful solution. For Germany, the concepts introduced in the last several years as pilot projects are shown in Table 2.

\section{$2.1 \quad$ Two-Bin System}

Another possibility is the two-bin system, which could be a compromise between the collection effort and separation of clean and dry valuables.

Waste is collected in two bins, a so-called dry bin, which contains recyclable material like plastic packaging, metals, textiles, minerals, and other non-sticking or wet material. The wet bin contains the biowaste fraction, including garden waste and residuals with high moisture content like diapers and hygienic products. There have been several research attempts at implementing a double-bin system in Germany, but the advantages of this system haven't been clear enough for widespread establishment [14], or the differing interests of market players. Under different conditions, a double-bin system could be effective regarding the different aims of national waste management programs. Introducing segregation systems 
step by step, it seems appropriate to start with the most economic and ecologically relevant waste stream to extract in one separate bin.

\subsection{Three-Bin System}

When three bins are used for household collection, usually the fractions of residual waste, biowaste, and a valuables fraction are collected separately. The understanding of valuables differs from country to country. Especially in Germany, the valuables bin is for collecting packaging that mostly consists of plastic and metal packaging. This collection and recycling system is paid for by the packaging producers according to an extended producer responsibility system.

\subsection{Four-Bin System}

Collection of four different single fractions at the household level requires a welldeveloped waste management system like the one found in Germany. Due to several investigations, this evidently does not lead to the best recycling efficiency because of the influence of some other factors which should be described in Sect. 3 (Fig. 2).

\subsection{Commingled System}

When commingled collection systems are used, different valuables are gathered in one mixed (commingled) material stream instead of the separate collection of highquality mono fractions (See [11]). This can often be seen in countries or municipalities that do not have the economic power to establish more bin collection

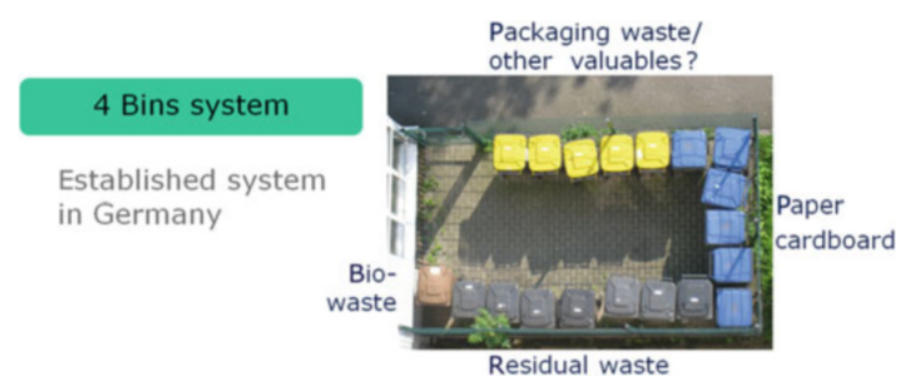

Fig. 2 The most common collection scheme in Germany (door-to-door collection of packaging waste, paper/cardboard, residual and biowaste) 
systems, among other reasons like availability of space and public collection behavior and awareness.

\section{Success Factors for Implementation}

Before separate collection can be implemented successfully, certain prerequisites are required. The chosen waste streams have to be technically recyclable and available with a high share in the original waste stream (see [11]). The design of products in the chosen waste stream must allow for the accessibility of the relevant valuable materials [15]. For example, plastic products like packaging should consist of different, easy-to-segregate types of plastic. Furthermore, it is important to establish a comprehensive collection, at least for the European situation, but can be carried over to a situation with rudimentary collection systems. Another factor is the need for transparent and valid data [15]. Only with reliable data are secure planning and investment calculations possible. For collection schemes in Europe or well-developed urban areas in China, respectively, that are already established, it is useful to orient toward the best-performing recycling infrastructures for further progress and optimization. At this level of implementation there are challenges regarding the effectiveness and efficiency and what the optimal technical and organizational set-up of the whole recycling chain is [15].

For rural areas, a survey about the introduction of source separation was carried out, which is described in [16]. The authors found out that important success factors include a share of awareness, convenience and sufficient separation facilities, and the willingness to pay. Furthermore, it has been proven for the rural study area in China that annual household income and location significantly influence the willingness to pay (see [16]). Also, the political entities can support the implementation process by funding the desirable behavior of the public (subsidizing schemes for municipalities or incentive systems for households to participate).

\subsection{Separation of the Most Suitable Waste Streams}

In this book, the relevant material streams for segregation are considered in [17, 18] (biowaste), [19] (WEEE), and [20] (plastics). This section focuses on the separation of biowaste seen as one of the most effective opportunities. It is necessary under pervasive economic limitations to concentrate on the most economic valuables, which allow the reduction in the environmental effects in the most eco-efficient way, i.e. the reduction of environmental damage at the lowest cost.

Looking worldwide, the major waste management challenge is the reduction in landfill gas emissions. Separating organic waste as the main part of household wastes could reduce these emissions the most. Ensuring the degradation of organic 


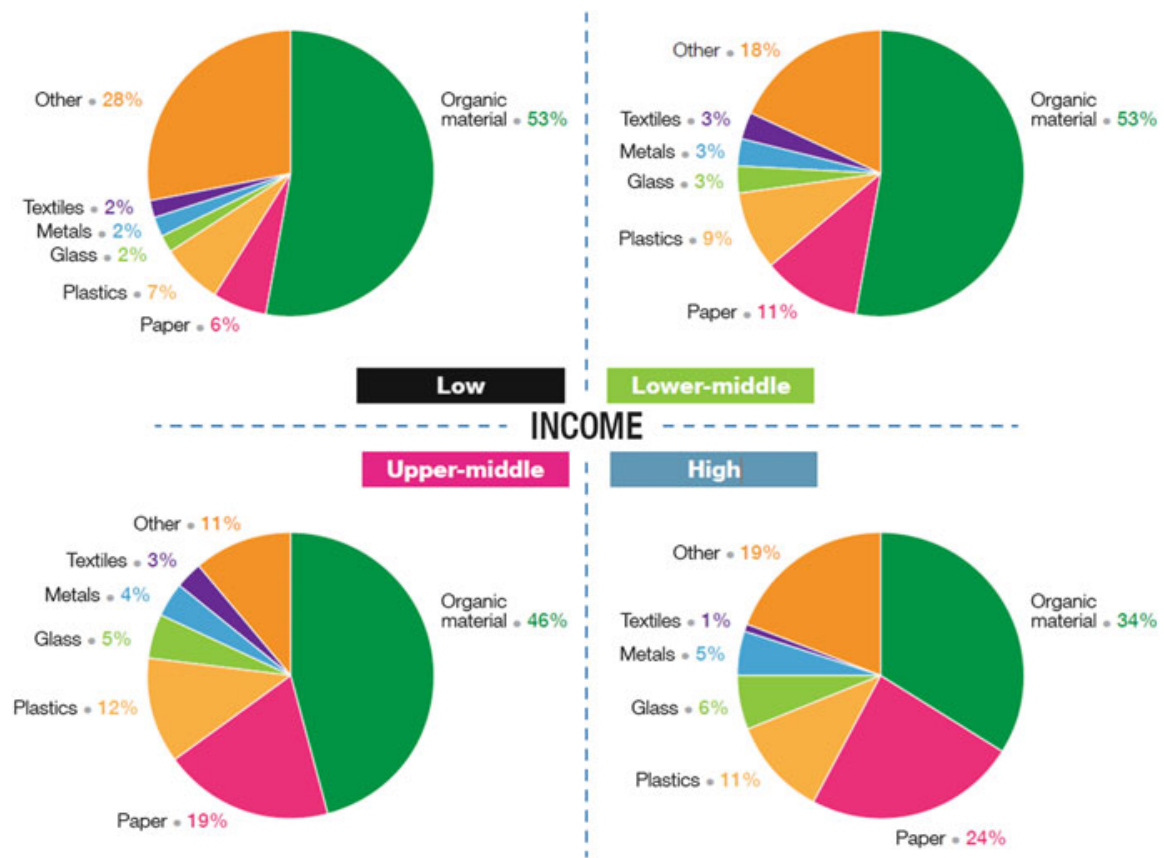

Fig. 3 Average national composition of household wastes depending on the different socioeconomic status goals, taken from [4] generated from other sources

material under controlled conditions in composting plants avoids methane gas production within landfills (see [6]).

Furthermore, the separation of biowaste from the residual waste stream leads to a decrease in water content, and therefore to an increase in dry matter in the residual waste stream.

Looking at waste compositions in countries all over the world, biowaste has the largest share in the overall generation (see Fig. 3).

Two of the major UNEP waste management goals are to cut food waste generation and food losses during production in half, respectively. Biowaste handling therefore seems to be one of the big issues in introducing waste separation schemes [4].

\subsection{Qualities of Output}

For established recycling markets, increasing the efficiency of separation systems by improving the qualities of the sorting products is one of the biggest challenges. Due to the calculation of recovery rates by input material amounts, recycling facilities concentrate on increasing their input amounts to generate high revenues 
for reception rather than the effort of high prices for good quality recycling material, especially in the case of Germany.

How prices for waste management tasks influence the waste management situation of a country is shown in [21].

For other collection schemes with a high share of informal collectors and therefore a high share of manual sorting, the quality issues are particularly regulated by the trade relations between the sorting people and the buying companies. The better the quality provided by the separation and recovery chain, the less environmental-political regulations are necessary. This can be seen in established, well-functioning trading systems of valuable materials all over the world in regions with large informal sector activities. This obviously occurs in missing or underdeveloped national waste management systems (see also Sects. 3.5 and 3.6).

As an example, for securing the quality of recycling material, the current Chinese policy of the "National Sword" can be mentioned [22]. It is intended to prevent the illegal smuggling of bad-quality recycling material, especially plastics such as WEEE. The campaign is the continuation of "Operation Green Fence" - the Chinese government effort to ensure high quality (uncontaminated material) for the recycling market, among other objectives like preventing illegal imports of household and hazardous wastes.

\subsection{Role of Waste Incineration}

It is scientifically proven that waste incineration does not necessarily impede recycling implementation efforts. In [23], some conclusions were made about the suitable combinations of recovery of materials and energy.

As can be seen in [7], it was mentioned that the same amounts of GHG could be saved by recycling and incineration processes. Following developments in Europe, a combination of high-efficient waste incineration for materials not suitable for recycling together with a focus on eco-efficient recycling turns out to be the best allocation between the interests of climate change mitigation, avoiding waste disposal hazards and using material cycles for enabling the best working circulating economy. For this, a blanket ban on landfilling is not seen as expedient, but rather the implementation of subsidies for efficient waste-to-energy technology and recycling products (Recommendations from [3]).

\subsection{Separation Technology}

Separation technology is evidently necessary for efficient segregation and to ensure high-quality recycling output, which is needed for an economically feasible recycling industry (see $[10,11,17])$. 
The most innovative development in the area of recycling was the implementation of automatic identification units on the basis of X-ray, NIR, TV cameras, etc. (see [21]).

The technical factors for economically feasible material recovery are comprehensive collection in the coverage area. In Germany, the daily collection rate for packaging waste ranges from 0.02 to $0.2 \mathrm{~kg}$ per capita per day (7-80 kg/year) [13]. Causes are seen in different regional consumer habits and varying socioeconomic conditions.

\subsection{Integration of the Informal Sector}

The informal sector still plays an important role in Chinese rural and metropolitan areas. Scavengers often collect recyclables at the source. Residents sell their recyclables to buyers at the household level door-to-door. Beneath that, the informal waste collection and marketing of related streams takes place at every stage of the waste handling process. This practice strongly influences the flow of the waste stream [24]. For the urban regions in China, informal recycling rates were estimated in the range of 17-38\% [25]. But there is a lack of scientific information about the informal waste sector in China. It can be assumed that the informal sector decreases due to the increasing level of organized waste management in all Chinese regions.

\subsection{Measures for the Strict Enforcement of Legislative Regulations on Source Separation}

Though a law came into force in China in 2008 prohibiting plastic bags, its implementation cannot be sufficiently controlled.

Punishment is necessary, as stated by Prof. Li Yong during the roundtable discussion at the Shanghai Workshop. If there are no other economic incentives for the stakeholders (e.g., public or recycling companies), pushing the mechanism via legislation should provide support. This could mean rewarding systems for avoiding residual waste or the enactment of recycling laws as they are found in Europe. For German waste legislation systems and the measures included for the implementation of source separation schemes in the 1990s, see [26].

\subsection{Summary of Success Factors}

In Table 3 the most important success factors are sorted by different categories like policies, waste characteristics, technical, economic, and social aspects. The factors 
Table 3 Factors and their conditions for enabling eco-efficient implementation (adapted from $[15,27])$, the chapters of this book and the roundtable discussion at the 2016 Shanghai workshop

\begin{tabular}{|c|c|c|c|c|c|}
\hline & Factor & $\begin{array}{l}\text { Success } \\
\text { requirement } \\
\text { level for } \\
\text { implementation }\end{array}$ & $\begin{array}{l}\text { Successful } \\
\text { condition/ } \\
\text { description }\end{array}$ & $\begin{array}{l}\text { Percent of } \\
\text { case studies } \\
\text { as a barrier }\end{array}$ & Source \\
\hline 1 & $\begin{array}{l}\text { Government } \\
\text { policy }\end{array}$ & Medium & $\begin{array}{l}\text { Presence of regu- } \\
\text { lations, enforce- } \\
\text { ment of laws, and } \\
\text { use of incentive } \\
\text { schemes }\end{array}$ & 63 & [27] \\
\hline 2 & $\begin{array}{l}\text { Legislation/ } \\
\text { monitoring/ } \\
\text { enforcement }\end{array}$ & Medium/high & $\begin{array}{l}\text { External factor, } \\
\text { which especially } \\
\text { is needed in situ- } \\
\text { ations with low } \\
\text { economic incen- } \\
\text { tives for imple- } \\
\text { mentation itself }\end{array}$ & n. considered & $\begin{array}{l}\text { Hagelüken [15], } \\
\text { stated by Chi- } \\
\text { nese Waste } \\
\text { Management } \\
\text { Professors dur- } \\
\text { ing roundtable } \\
\text { discussion }\end{array}$ \\
\hline 3 & $\begin{array}{l}\text { Government } \\
\text { finances }\end{array}$ & Medium/high & $\begin{array}{l}\text { Cost of opera- } \\
\text { tions, } \\
\text { budget allocation } \\
\text { to MSWM, sta- } \\
\text { bility/reliability } \\
\text { of funds }\end{array}$ & 77 & {$[27]$} \\
\hline 4 & $\begin{array}{l}\text { Landfill tipping } \\
\text { fee }\end{array}$ & Very high & $\begin{array}{l}\text { The rise of the } \\
\text { tipping fee is seen } \\
\text { as the starting } \\
\text { point for } \\
\text { European Sepa- } \\
\text { rate Collection } \\
\text { schemes }\end{array}$ & n. considered & [21] \\
\hline 5 & $\begin{array}{l}\text { Waste } \\
\text { characterization }\end{array}$ & Medium & $\begin{array}{l}\text { Assessment of } \\
\text { generation and } \\
\text { recovery rates, } \\
\text { and composition } \\
\text { of waste stream }\end{array}$ & 67 & [27] \\
\hline 6 & $\begin{array}{l}\text { Waste collec- } \\
\text { tion and } \\
\text { segregation }\end{array}$ & High & $\begin{array}{l}\text { Presence and effi- } \\
\text { ciency of formal } \\
\text { or informal col- } \\
\text { lection and sepa- } \\
\text { ration by } \\
\text { scavengers, the } \\
\text { municipality, or } \\
\text { private } \\
\text { contractors }\end{array}$ & 79 & [27] \\
\hline 7 & $\begin{array}{l}\text { Collection } \\
\text { infrastructure }\end{array}$ & Medium/high & $\begin{array}{l}\text { Efficient and con- } \\
\text { venient collection } \\
\text { systems, amount } \\
\text { of waste trucks, } \\
\text { recycling points, } \\
\text { bin distribution, } \\
\text { etc. }\end{array}$ & n. considered & [15] \\
\hline
\end{tabular}


Table 3 (continued)

\begin{tabular}{|c|c|c|c|c|c|}
\hline & Factor & $\begin{array}{l}\text { Success } \\
\text { requirement } \\
\text { level for } \\
\text { implementation }\end{array}$ & $\begin{array}{l}\text { Successful } \\
\text { condition/ } \\
\text { description }\end{array}$ & $\begin{array}{l}\text { Percent of } \\
\text { case studies } \\
\text { as a barrier }\end{array}$ & Source \\
\hline 8 & $\begin{array}{l}\text { Separation } \\
\text { technology }\end{array}$ & Medium/high & $\begin{array}{l}\text { Especially for } \\
\text { countries with } \\
\text { well-established } \\
\text { Waste Manage- } \\
\text { ment Systems a } \\
\text { high standard of } \\
\text { recycling tech- } \\
\text { nology leads to } \\
\text { high and good } \\
\text { quality output } \\
\text { rates }\end{array}$ & n. considered & [21] \\
\hline 9 & $\begin{array}{l}\text { Household } \\
\text { education }\end{array}$ & Medium/high & $\begin{array}{l}\text { Extent of knowl- } \\
\text { edge of waste } \\
\text { management } \\
\text { methods and } \\
\text { understanding } \\
\text { linkages between } \\
\text { human behavior, } \\
\text { waste handling, } \\
\text { and health/sanita- } \\
\text { tion/environment } \\
\text { within } \\
\text { households }\end{array}$ & 69 & [27] \\
\hline 10 & $\begin{array}{l}\text { Household } \\
\text { economics }\end{array}$ & Low & $\begin{array}{l}\text { Individuals' } \\
\text { income influenc- } \\
\text { ing waste han- } \\
\text { dling behavior } \\
\text { (reuse, recycling, } \\
\text { illegal dumping), } \\
\text { presence of waste } \\
\text { collection/dis- } \\
\text { posal fees, and } \\
\text { willingness to pay } \\
\text { by residents }\end{array}$ & 22 & [27] \\
\hline 11 & $\begin{array}{l}\text { Stakeholder } \\
\text { behavior and } \\
\text { motivation } \\
\text { (consumers/ } \\
\text { emotional link, } \\
\text { OEMs/EPR } \\
\text { culture, } \\
\text { retailers, } \\
\text { recyclers) }\end{array}$ & Medium/high & $\begin{array}{l}\text { Identification of } \\
\text { the stakeholders } \\
\text { with }\end{array}$ & n. considered & [15] \\
\hline
\end{tabular}

(continued) 
Table 3 (continued)

\begin{tabular}{|c|c|c|c|c|c|}
\hline & Factor & $\begin{array}{l}\text { Success } \\
\text { requirement } \\
\text { level for } \\
\text { implementation }\end{array}$ & $\begin{array}{l}\text { Successful } \\
\text { condition/ } \\
\text { description }\end{array}$ & $\begin{array}{l}\text { Percent of } \\
\text { case studies } \\
\text { as a barrier }\end{array}$ & Source \\
\hline 12 & $\begin{array}{l}\text { MSWM } \\
\text { administration }\end{array}$ & Medium & $\begin{array}{l}\text { Presence and } \\
\text { effectiveness of } \\
\text { private and/or } \\
\text { public manage- } \\
\text { ment of waste } \\
\text { (collection, } \\
\text { recovery, } \\
\text { disposal) }\end{array}$ & 44 & [27] \\
\hline 13 & $\begin{array}{l}\text { MSWM per- } \\
\text { sonnel } \\
\text { education }\end{array}$ & Medium/high & $\begin{array}{l}\text { Extent of trained } \\
\text { laborers and } \\
\text { skilled profes- } \\
\text { sionals in MSWM } \\
\text { positions }\end{array}$ & 83 & [27] \\
\hline 14 & MSWM plan & Medium & $\begin{array}{l}\text { Presence and } \\
\text { effectiveness of } \\
\text { an integrative, } \\
\text { comprehensive, } \\
\text { long-term } \\
\text { MSWM strategy }\end{array}$ & 50 & [27] \\
\hline 15 & $\begin{array}{l}\text { External collec- } \\
\text { tion incentives } \\
\text { (e.g., leasing, } \\
\text { deposits, etc.) }\end{array}$ & High & $\begin{array}{l}\text { The higher the } \\
\text { amount subsi- } \\
\text { dized recycling } \\
\text { prices the more } \\
\text { stakeholder } \\
\text { groups will } \\
\text { involve in the } \\
\text { business }\end{array}$ & n. considered & [15] \\
\hline 16 & $\begin{array}{l}\text { Local recycled } \\
\text { material market }\end{array}$ & High & $\begin{array}{l}\text { Existence and } \\
\text { profitability of } \\
\text { market systems } \\
\text { relying on } \\
\text { recycled-material } \\
\text { throughput, } \\
\text { involvement of } \\
\text { small businesses, } \\
\text { middlemen, and } \\
\text { large industries/ } \\
\text { exporters }\end{array}$ & 36 & [27] \\
\hline 17 & Material value & High & $\begin{array}{l}\text { Intrinsic factor, } \\
\text { good quality with } \\
\text { low impurities/ } \\
\text { contaminations } \\
\text { leads to profitable } \\
\text { prices for } \\
\text { recycling material }\end{array}$ & n. considered & [15] \\
\hline
\end{tabular}

(continued) 
Table 3 (continued)

\begin{tabular}{|c|c|c|c|c|c|}
\hline & Factor & $\begin{array}{l}\text { Success } \\
\text { requirement } \\
\text { level for } \\
\text { implementation }\end{array}$ & $\begin{array}{l}\text { Successful } \\
\text { condition/ } \\
\text { description }\end{array}$ & $\begin{array}{l}\text { Percent of } \\
\text { case studies } \\
\text { as a barrier }\end{array}$ & Source \\
\hline 18 & $\begin{array}{l}\text { Qualities of } \\
\text { output }\end{array}$ & High & $\begin{array}{l}\text { Higher quality } \\
\text { leads to better } \\
\text { prices and to } \\
\text { more acceptance } \\
\text { by the users of } \\
\text { recycling mate- } \\
\text { rial, which leads } \\
\text { to more economic } \\
\text { feasibility }\end{array}$ & n. considered & Section 3.2 \\
\hline 19 & $\begin{array}{l}\text { Separation of } \\
\text { the most suit- } \\
\text { able waste } \\
\text { streams }\end{array}$ & High & $\begin{array}{l}\text { Concentration on } \\
\text { the dominant or } \\
\text { most economic } \\
\text { waste streams is } \\
\text { the most cost } \\
\text { efficient way to } \\
\text { solve the major } \\
\text { challenges like } \\
\text { reducing disposal } \\
\text { amounts and } \\
\text { enable economic } \\
\text { feasible waste } \\
\text { management }\end{array}$ & n. considered & Section 3.1 \\
\hline 20 & $\begin{array}{l}\text { Business } \\
\text { model/lifecycle } \\
\text { type (B2C, } \\
\text { B2B) }\end{array}$ & High & $\begin{array}{l}\text { Intrinsic factor, } \\
\text { handling of B2B } \\
\text { recycling material } \\
\text { enables high } \\
\text { purities }\end{array}$ & n. considered & [15] \\
\hline 21 & $\begin{array}{l}\text { Complexity/ } \\
\text { heterogeneity } \\
\text { (product com- } \\
\text { position and } \\
\text { design) }\end{array}$ & Low & $\begin{array}{l}\text { Recyclability of } \\
\text { collected waste } \\
\text { material }\end{array}$ & n. considered & [15] \\
\hline 22 & $\begin{array}{l}\text { Technological } \\
\text { and human } \\
\text { resources }\end{array}$ & Medium/high & $\begin{array}{l}\text { Availability and } \\
\text { effective use of } \\
\text { technology and/or } \\
\text { human workforce } \\
\text { and the safety } \\
\text { considerations of } \\
\text { each }\end{array}$ & 58 & [27] \\
\hline 23 & $\begin{array}{l}\text { Land } \\
\text { availability }\end{array}$ & Low & $\begin{array}{l}\text { Land attributes } \\
\text { such as terrain, } \\
\text { ownership, and } \\
\text { development dic- } \\
\text { tating MSWM }\end{array}$ & 0 & [27] \\
\hline
\end{tabular}

(continued) 
Table 3 (continued)

\begin{tabular}{l|l|l|l|l|l}
\hline & & $\begin{array}{l}\text { Success } \\
\text { requirement } \\
\text { level for } \\
\text { implementation }\end{array}$ & $\begin{array}{l}\text { Successful } \\
\text { condition/ } \\
\text { description }\end{array}$ & $\begin{array}{l}\text { Percent of } \\
\text { case studies } \\
\text { as a barrier }\end{array}$ & Source \\
\hline 24 & $\begin{array}{l}\text { Role of waste } \\
\text { incineration }\end{array}$ & Medium/low & $\begin{array}{l}\text { WI do not impede } \\
\text { source separation, } \\
\text { can be established } \\
\text { together like in } \\
\text { Europe }\end{array}$ & n. considered & Section 3.3 \\
$\begin{array}{l}\text { Integration of } \\
\text { the informal } \\
\text { sector }\end{array}$ & Medium/high & $\begin{array}{l}\text { Integration leads } \\
\text { to better working } \\
\text { conditions for } \\
\text { workers and } \\
\text { enables access to } \\
\text { the valuable } \\
\text { material streams } \\
\text { out of the infor- } \\
\text { mal sector }\end{array}$ & n. considered & Section 3.5 & \\
\hline
\end{tabular}

shown are collected from this book or referring to literature sources and show the success factors both for implementation and the running of separation or recycling systems, too.

Each factor is assigned to an "importance" or "success requirement" level. It can be seen that some factors are more required than others. In this author's assessment it is shown that economic factors like presence of the demand for recycling products or the material value push recycling, because there informal or formal business structures arise. Troschinetz and Mihelcic [27] assessed some factors by a survey of stakeholders in different developing countries. The stakeholders had to evaluate the barriers for establishing sustainable recycling. In this survey the highest rated factor was the education and experience of the involved MSW staff and decision makers.

The interdependencies of the 12 factors detected by Troschinetz and Mihelcic [27] are shown in Fig. 4. It can be seen that the most connections are around factor 4 (presence of a waste collection and segregation system). This proves that successful implementation is a mandatory basis for a sustainable waste management system.

\section{Conclusion}

The main driving force to implementing waste minimization and cleaner technologies, and to exploit waste economically and feed it back into the production cycle, is the price of the final waste disposal, as Prof. Bilitewski emphasized during the roundtable discussion at the end of the workshop. It means that the main factor for 


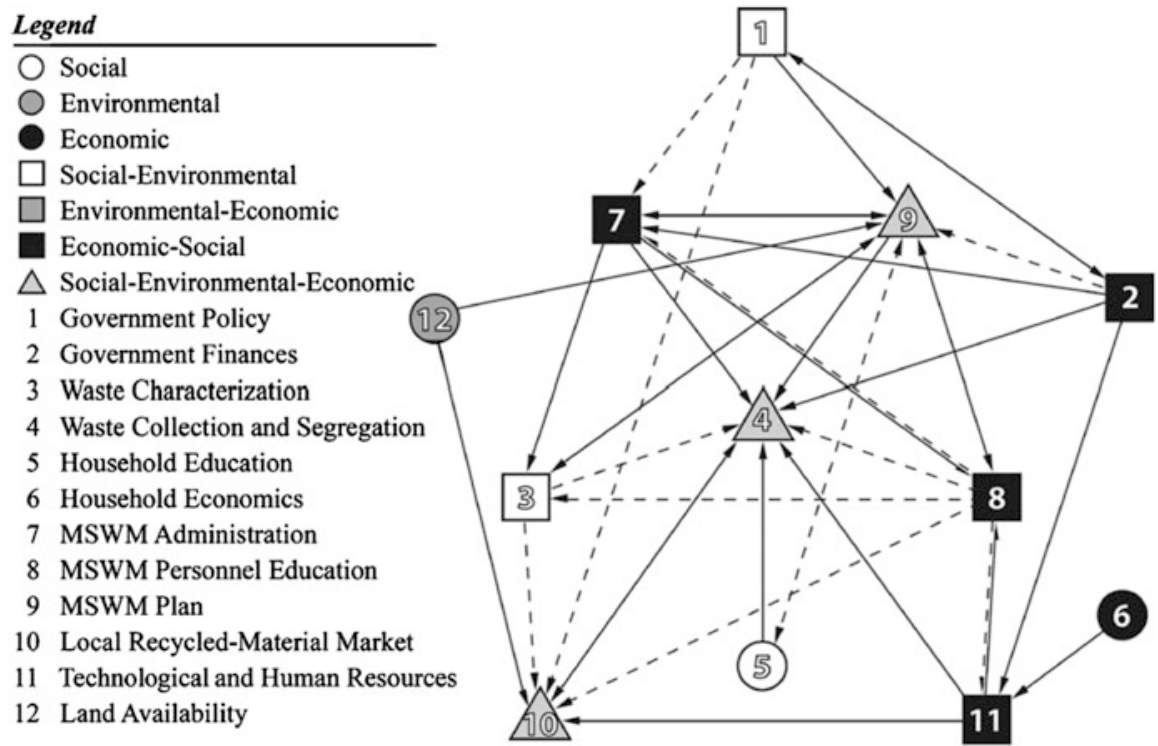

Fig. 4 Collaboration web illustrating relationships among the 12 factors influencing sustainable recycling in developing countries. There are institutions responsible for each factor's activities. A solid line represents necessary collaborating institutions for a given factor to contribute to sustainable recycling, whereas a dashed line implies a heightened influence on sustainable recycling by a given factor upon institutional interaction. Arrows show how information flows from one MSWM institution to another; this defines the stakeholder involvement required of each party. Node shading and shape identify the sustainability dimensions governing MSWM institutions' responsibilities based on relationships among factors. Copied from [27]

successful implementation is naturally the costs. The implementation of costcovering source separation schemes leads to rising waste fees. So only with rising opportunity costs for sanitary landfilling or other disposal operations can this financial effort be equalized.

Economic viability could be ensured by intrinsic or extrinsic factors. In marketdriven societies like in Germany, intrinsic factors like the monetary value of recycled material outputs traded on the recycling market often are insufficient for the increasing of recycling activities. Costs that are too high compared to the prices of virgin materials impede a relevant substitution by such materials. Therefore, some extrinsic factors like the environmental policies are needed to encourage a comprehensive implementation of the separation of waste streams. The promotion of recycled materials could be one example. The Electronic Product Environmental Assessment Tool (EPEAT) could be mentioned as an example. EPEAT comes from the Green Electronics Council in the United States, and is the leading assessing organization of environmental lifecycle standards. The program evaluates computer desktops and laptops, monitors with 51 environmental criteria, and awards EPEAT Bronze, Silver or Gold certifications. EPEAT now covers 43 countries, 
over 60 participating manufacturers and more than 4,400 environmentally preferable electronic products [28].

The combination of these factors can lead to successful implementation at an improved eco-efficiency and ecological effects that are not intrinsic drivers for the implementation of source separation.

\section{Overall Conclusion}

For China and other countries with rising waste management challenges, source separation has been proven to be one of the fundamental solutions for the sustainable handling of resources and achievement of a circular economy.

The separation of the biowaste stream from the residual waste flow can be seen as the most important, easiest, and most effective way of reducing waste amounts for landfills, especially for current conditions in China. This could be stated for Germany and other European countries, too, with sophisticated collection systems and raised experience over several decades. But, especially in Germany, the increase in separated biowaste handling in Germany has slowed down because of the competitive situation between using the renewable energy content of biowaste during the residual waste treatment and the underlying industrial interests. Of importance is the consideration of national and regional conditions when trying to implement source separation. Over and above that and finally said, moving toward a low waste economy, i.e. pushing waste reduction in general, is the most environmental and economic path that has to be re-proven in the coming years under the paradigm of sustainability.

\section{References}

1. Dehoust G, Schüler D, Vogt R, Giegrich J (2010) Climate protection potential in the waste management sector - examples: municipal waste and waste wood. Report by order from the Federal Environment Agency of Germany

2. Fischer C (2013) Municipal waste management in Germany. Official country report for the European Environment Agency

3. Hogg D, Ballinger A (2015) The potential contribution of waste management to a low carbon economy - main report. Eunomia Research \& Consulting, Bristol

4. Wilson DC, Rodic L, Modak P, Soos R, Rogero AC, Velis C, Iyer M, Simonett O (2015) Global waste management outlook, Geneva. ISWA report ordered by the UNEP. ISBN: 978-92-807-3479-9

5. Vogt R, Derreza-Greeven C, Giegrich J, Dehoust G, Möck A, Merz C (2015) The climate change mitigation potential of the waste sector. Report by order from the Federal Environment Agency of Germany

6. Ziyang L, Zhilin X, Zhaowen C, Tiantao Z, Bofeng C (2017) The waste management system in China and greenhouse gas emission inventories. Handb Environ Chem. doi:10.1007/698_ 2017_32 
7. Wünsch C, Simon FG (2017) The reduction of greenhouse gas emissions through the sourceseparated collection of household waste in Germany. Handb Environ Chem. doi:10.1007/698_ 2017_35

8. Friege $\mathrm{H}$ (2017) Separate collection of waste fractions - economic opportunities and problems. Handb Environ Chem. doi:10.1007/698_2017_24

9. Nassour A et al. (2017) Separation by manual sorting at home: state of the art in Germany. Handb Environ Chem. doi:10.1007/698_2017_26

10. Schingnitz D (2017) Separation of MSW in treatment plants (MBT). Handb Environ Chem. doi:10.1007/698_2017_27

11. Clausen A, Althaus M, Pretz T (2017) Commingled waste collection as chance for technical separation - alternative collection systems. Handb Environ Chem. doi:10.1007/698_2017_29

12. Seyring N, Dollhofer M, Weißenbacher J, Herzog M, McKinnon D, Bakas I (2015) Assessment of separate collection schemes in the 28 capitals of the EU. Final report, Nov 2015. BIPRO/CRI

13. Dehoust G, Christiani J (2012) Analyse und Fortentwicklung der Verwertungsquoten für Wertstoffe (Analysis and further development of recovery rates for valuables). Report by order from the Federal Environment Agency of Germany

14. Schröer R, Morgan RM, Urban AI (2007) Nasse + trockene Restabfalltonne Ein neues System für Kassel? (Wet and dry bin - a new system for the city of Kassel?). In: Urban AI (ed) Weiterentwicklung der Abfallwirtschaft (Further development of waste management), vol 7. UNIK-AT, Berlin, pp 111-122

15. Hagelüken C (2016) Circular economy for metals - chances, challenges and limitations (German). Presentation at 23rd colloquium of waste management and contaminated sites, Dresden, 3 Nov 2016

16. Chao Z, Hangfen L, Fafa X, Dongjie N, Youcai Z (2017) Source-separated collection of rural solid waste in China. Handb Environ Chem. doi:10.1007/698_2017_30

17. Fricke K, Heußner C, Hüttner A, Turk T (2017) Recycling of biowaste experience with collection, digestion and quality in Germany. Handb Environ Chem doi:10.1007/698_2017_34

18. Long Y, Shen D (2017) The effect of source separation on the waste disposal process: case study in Hangzhou. Handb Environ Chem. doi:10.1007/698_2017_31

19. Salhofer S (2017) E-waste collection and treatment options: a comparison of approaches in Europe, China and Vietnam. Handb Environ Chem. doi:10.1007/698_2017_36

20. Kuchta K (2017) Circular economy opportunities for plastic. Handb Environ Chem

21. Bilitewski B (2015) Years of source separation in Germany and its future. Handb Environ Chem. doi:10.1007/698_2017_33

22. Perchard E (2017) China starts National Sword campaign to target 'foreign waste' smuggling. Press report from 23rd February 2017. www.resource.do. Accessed 27 Feb 2017

23. Quicker P (2017) Thermal treatment as a chance for material recovery. Handb Environ Chem. doi:10.1007/698_2017_28

24. Zhang DQ, Tan SK, Gersberg RM (2010) Municipal solid waste management in China: status, problems and challenges. J Environ Manag 91:1623-1633

25. Linzner R, Salhofer S (2014) Municipal solid waste recycling and the significance of informal sector in China. Waste management and research, vol 32. Sage, London, pp 896-907

26. Dornack C (2017) Waste policy for source separation in Germany. Handb Environ Chem

27. Troschinetz AM, Mihelcic JR (2009) Sustainable recycling of municipal solid waste in developing countries. Waste Manag 29:915-923

28. EPEAT (2016) http://www.epeat.net. Accessed 13 Dec 2016 